\title{
Política e poder: mulheres presentes no Legislativo!
}

\section{Os bastidores da tribuna: mulher, política e poder no Maranhão.}

MERREIRA, Mary.

O livro de Mary Ferreira, publicado pela Universidade Federal do Maranhão e que traz o prefácio da socióloga Lucila Scavone, apresenta uma rica pesquisa de campo sobre as deputadas do Maranhão e de Portugal, cuja pesquisa se apoia na técnica de trajetória de vida dos sujeitos estudados. Já pela técnica de pesquisa selecionada por Mary Ferreira, entendemos que a autora não se interessa por abstrações macros e teóricas. Mais do que isso, ela quer identificar os sujeitos concretos (mulheres) no seu cotidiano microssociológico, compreendendo sua origem social, sua relação com a política, sua formação, os recursos (ou capitais) que disponibiliza, sua agenda de projetos mobilizados, sua sensibilidade política, sua construção discursiva, seus aliados, seus opositores e os espaços sociais que ocupam.

Com a constatação inicial de que houve aumento significativo de presença feminina no Legislativo, mas que essa mudança não tem consubstanciado em mudanças estruturais nas relações de gênero, a autora busca avaliar a participação das mulheres nos espaços de poder, em particular no Legislativo, além de analisar de que forma a ação feminina é prejudicada à medida que são analisadas as relações desiguais no número de cadeira ocupada por mulheres.

Seus dados indicam que o cenário do poder (sobretudo no estado do Maranhão, mas não somente) ainda é dominado por homens. brancos, com formação superior e de origem social média ou rica. Nesse sentido, pobres, negros e mulheres formariam a exceção nesse espaço social. Sua constatação dialoga com os dados de nossas pesquisas sobre os gestores do mercado financeiro. Nela, identificamos que negros/as, mulheres, índios/as e pessoas de origem popular estão excluídos/as ou parcialmente excluídos/as. Da mesma forma, as poucas mulheres encontradas incorporam a violência simbólica produzida do campo financeiro e passam a reproduzir as crenças dos engajados nesse espaço. Intitulamos os gestores do mercado financeiro como "elite", já que são capazes de criar a doxa (senso comum). Parece-nos que o campo político estudado por Mary Ferreira também possui uma "elite" que trabalha para a manutenção e a reprodução de suas crenças, com a entrada de filhos, netos e afilhados no cenário políitico e a exclusão daqueles que não compartilham do mesmo "mito de origem", sendo no caso estudadas as mulheres.

Para Ferreira, a ausência das mulheres nos espaços decisórios coloca em cheque a tão propalada democracia liberal. É nesse momento do texto que a autora aborda o debate das cotas, polemizando sobre os seus limites e avanços. Para a autora, as cotas tendem a ser compreendidas como um novo conceito de democracia, ou seja, de democracia paritária que expressa $\circ$ novo paradigma políico e garante a paridade e a participação de indivíduos historicamente excluídos.

Sem se contentar com respostas prontas, Mary Ferreira questiona os sentidos políticos das cotas e conclui: mesmo que as cotas não garantam às mulheres real acesso ao poder, esse dispositivo traduz o reconhecimento das desigualdades de gênero, da exclusão histórica das mulheres. Portanto, trata-se de uma importante estratégia, já que, antes de tudo, revela discursos historicamente eufemizados pela dominação masculina e pela violência simbólica resultado dessa.

De outra parte, o trabalho empírico de Mary Ferreira nos fornece elementos concretos para a atualização do debate em torno da questão de gênero, por isso é importante ficar atento aos dados que a autora levanta:

- sobre a inserção das mulheres no espaço político, a autora destaca três formas: laços familiares, militância política ou destaque em suas atividades profissionais. $O$ canal familiar é visto pela autora como o mais evidente;

- sobre a produtividade das deputadas, a autora nota que as mulheres apresentam, em termos proporcionais, maior número de projeto que os deputados (11,54\% a mais); e 
- sobre o perfil dos projetos apresentados pelas deputadas, a autora argumenta que tais projetos não diferem, no geral, dos projetos apresentados pelos deputados, mas que existe uma distinção na natureza e no alcance deles, bem como na preocupação de gênero em alguns deles. A autora acrescenta que as parlamentares reconhecem as desigualdades de gênero, na medida em que seus projetos representam ações que procuram inverter essas desigualdades. O projeto sobre microcrédito citado pela autora, é um exemplo concreto nessa direção.

Em diálogo com seus dados e inspirada por Foucault e Bourdieu, ' Mary Ferreira foge de leituras que colocam as relações de poder como relações fixas, isoladas e unilaterais. Para Ferreira, as relações de poder são complexas, relativas, recíprocas, mediadas pela sedução, pelo consentimento e pela violência simbólica Portanto, mesmo sem negar os limites e as tensões para a inserção qualitativa da mulher no mundo da política, bem como para as suas transgressões no mundo do poder, Mary Ferreira nos mostra concretamente o crescimento quantitativo das mulheres nas assembleias legislativas, no senado e em cargos executivos, fato que nos faz afirmar que a autora não se deixou seduzir pela opção teórica da reprodução das relações do poder em si mesma. Ou seja, apesar de tímidas, é possível perceber transformações de natureza microssociológica no campo do poder analisado pela autora.

Segundo Bourdieu, ${ }^{2}$ as transformações de uma sociedade acontecem como resultado de transformações cognitivas (culturais) nas mentes dos indivíduos (mundo subjetivo) e se expressam posteriormente nas leis, nas instituições, nos prédios, nos livros (mundo objetivo). Nesse sentido, a percepção do aumento quantitativo da presença de mulheres nos espaços políticos é importante, pois sinaliza que revoluções simbólicas invisíveis estão acontecendo nas categorias de pensamento da sociedade contemporânea ou nas convenções cognitivas, mesmo que não tenham, ainda, se expressado no mundo objetivo.
Se seguirmos a observação de Robert Merton, ${ }^{3}$ quem afirma que todas as teorias são autorrealizantes, devemos, como cientistas sociais, celebrar as tímidas mudanças apontadas por Ferreira, pois elas sinalizam que as peças do quebra-cabeça estão em mutação; que outras formas de rupturas e outras transgressões se desenham para as próximas gerações de mulheres. A eleição da presidenta, Dilma, em 2010 é um dado concreto e de significativo valor simbólico, já que possui eficácia nesse trabalho invisível (nas mentes) que nos levará em direção a uma transformação das categorias de pensamento.

Por tudo isso, o livro de Mary Ferreira pode ser lido por acadêmicos, por militantes e pela sociedade civil em geral, pois o seu texto alcança $o$ interesse de todos os públicos e mostra que a autora entendeu muito bem as lições de Bourdieu, ${ }^{4}$ qual seja, que, para fazer uma pesquisa rigorosa, não é necessário ser rígido consigo e com seu objeto de estudo. Apesar da militância política no tema, Ferreira soube equilibrar o tom da sua argumentação. Mesmo mantendo a paixão que possui pelo tema, não se deixou seduzir por caminhos e análises fáceis. Ao contrário, manteve o senso científico, aliado com sua indiscutível sensibilidade de militante.

\section{Notas}

1 Pierre BOURDIEU, 2007.

2 BOURDIEU, 2007.

${ }^{3}$ Robert MERTON, 1968.

${ }^{4}$ BOURDIEU, 2007.

\section{Referências}

BOURDIEU, Pierre. Razões práticas. Campinas: Papirus, 2007.

JARDIM, Maria A. Chaves. Entre a solidariedade e o risco: sindicatos e fundos de pensão no governo Lula. São Paulo: Annablume; FAPESP, 2009.

MERTON, Robert. Social Theory and Social Structure. New York: Free Press, 1968.

Maria A. Chaves Jardim Universidade Estadual Júlio de Mesquita Filho 